\title{
The study of antibacterial activity in enteric pathogens of Roselle (Hibiscus sabdariffa Linn.) by broth micro-dilution method
}

\author{
Bajaree Jantrapanukorn ${ }^{1 *}$, Sawanya Pongpraritt ${ }^{1}$, Pannapa Powthong ${ }^{1}$, Thanet Pheungphu ${ }^{2}$ \\ ${ }^{1}$ Faculty of Medical technology, Rangsit University, Pathumthanee, Thailand. ${ }^{2}$ Faculty of Phamacy, Rangsit University, Pathumthanee, Thailand.
}

\begin{tabular}{|c|c|}
\hline ARTICLE INFO & ABSTRACT \\
\hline Article history: & \multirow{8}{*}{$\begin{array}{l}\text { The crude water extract of Roselle (Hibiscus sabdariffa Linn.) was determined for its antibacterial activities on } \\
6 \text { bacterial reference strains and } 16 \text { isolates of enteric pathogens. Determination of minimum inhibitory } \\
\text { concentrations(MICs) by broth microdilution method with final concentration of Roselle extract between } 200 \text { - } \\
3.125 \mathrm{mg} / \mathrm{ml} \text { showed that Roselle extract could inhibit the growth of bacterial reference strains at MICs } 25 \\
\mathrm{mg} / \mathrm{ml} \text { on Aeromonas veronii biogroup sorbria ATCC } 9071 \text {, MICs } 50 \mathrm{mg} / \mathrm{ml} \text { on Yersinia enterocolitica ATCC } \\
9610 \text { and MICs } 100 \mathrm{mg} / \mathrm{ml} \text { on Aeromonas caviae ATCC } 15468 \text {, Aeromonas hydrophila ATCC } 35654 \text {, Vibrio } \\
\text { parahaemolyticus ATCC } 17802 \text {, Vibrio vulnificus ATCC } 27562 \text {. Roselle extract also exhibited its antibacterial } \\
\text { activities on enteric pathogens giving the MICs of } 25 \mathrm{mg} / \mathrm{ml} \text { on Edwardsiella tarda and Yersinia } \\
\text { pseudotuberculosis, the MICs of } 50 \mathrm{mg} / \mathrm{ml} \text { on Plesiomonas shigelloides, Salmonella arizonae, Salmonella } \\
\text { choleraesuis, Salmonella paratyphi A, Salmonella Typhi, Shigella boydii, Shigella dysenteriae, Shigella } \\
\text { flexneri, Shigella sonnei, Vibrio cholerae and Yersinia enterocolitica, the MICs of } 100 \mathrm{mg} / \mathrm{ml} \text { on Aeromonas } \\
\text { caviae, Aeromonas hydrophila and Salmonella enteritidis. The data indicated that Roselle extract could produce } \\
\text { antibacterial activities against enteric pathogens at various concentrations. The extract should be further study to } \\
\text { use as antibacterial agent for controlling these organisms. }\end{array}$} \\
\hline Received on: 08/07/2016 & \\
\hline Accepted on: 10/09/2016 & \\
\hline Available online: 30/05/2017 & \\
\hline Key words: & \\
\hline Roselle, Hibiscus sabdariffa & \\
\hline Linn., Minimal Inhibitory & \\
\hline $\begin{array}{l}\text { Concentration (MIC), Enteric } \\
\text { bacteria pathogen. }\end{array}$ & \\
\hline
\end{tabular}

\section{INTRODUCTION}

Emerging foodborne pathogens have become a major public health concern. Infectious diarrhoeal diseases are responsible for considerable morbidity and mortality, especially in developing countries (Thapar and Sanderson, 2004). According to WHO (2009) bulletin, diarrhea diseases account for an estimated annual 1.5 million deaths among children younger than five years old in the world. Antibiotics provide the main therapy for microbial (bacterial and fungal) infections. Although antibiotics play a vital role in the treatment of different diseases, they also have side effects. Altogether, overuse of antibiotics has become the major factor for the emergence and dissemination of multi-drug-resistant strains of several groups of microorganisms

\footnotetext{
* Corresponding Author

Bajaree Jantrapanukorn, Faculty of Medical technology, Rangsit University, Pathumthanee, Thailand.Email: NuBaMT @ gmail.com
}

and the spread of the new infections (Abdalla, 2011). Many naturally occurring compounds found in medicinal plants, herbs, and spices have been shown to possess antimicrobial activities against many foodborne pathogens. Use of herbal products as antimicrobial agents may provide the best alternative to the wide and injudicious use of synthetic antibiotics. The demand for plantbased therapeutics is increasing in both developing and developed countries because of growing recognition that they are natural products, non-narcotic, and easily biodegradable, producing minimum environmental hazards, having no adverse side effects, and being easily available at affordable prices. Thus, in light of the evidence of rapid global spread of resistant isolates, the need to find new antimicrobial agents is of paramount importance. Roselle, Hibiscus sabdariffa Linn. is a shrub belonging to the familyMalvaceae and thought to be a nature to Asia or Tropical Africa (Mahadevan et al., 2009). The crop is widely grown in the tropics for home use. The seeds contain protein (18.8-22.3\%), fat (19.1$22.8 \%$ ) and dietary fiber (39.5-42.6\%) (Rao, 1996). 
The leaf is reputed to contain protein, fat, carbohydrate, fiber, ash, calcium, phosphorus, iron, thiamine, $\beta$-carotene, riboflavin, niacin and ascorbic acid (Duke, 1979; Prerry, 1980). This medicinal herb commonly uses to make drink and pickle and used in folk medicine in the treatment of hypertension, liver diseases, and fever (Dalziel, 1973: Wang et al., 2000; Odigie et al. 2003; Akindahunsi et al., 2003). Hibiscus anthocyanins, a group of phenolic natural pigment present in the dried flower of Hibiscus rosasinensis, and $H$. sabdariffa have been found to have cardioprotective (Jonadet et al., 1990), hypocholesterolemic (Chen et al., 2003).

Anthocyanin pigments and other phenolic compounds (Hibiscus protocatechuic acid) also isolated from dried flowers of H. sabdariffa demonstrated protective effects against tert-butyl hydroperoxide-induced oxidative damage and hepatotoxicity both in vitro and in vivo (Liu et al., 2002). $H$. sabdariffa has been reported to be antiseptic, aphrodisiac, astringent, diuretic, emollient, purgative, sedative, stomachic, and tonic. It is also a folk remedy for abscesses, bilious conditions, cancer, cough, dysuria, and scurvy (Morton et al., 1987) and was also found to be anticarcinogenic (Fullerton et al., 2008). These findings contribute to support and qualify the importance of screening natural products. Conclusive information is, however, critical with regard to its role as an antimicrobial.

Therefore the objective of this study was to evaluate the antimicrobial activities of Roselle ( $H$. sabdariffa) on enteric bacterial pathogens either reference strain and also clinical isolated using the broth micro-dilution method.

\section{MATERIALS AND METHODS}

\section{Test microorganisms}

The tested organisms were bacterial reference strains included Aeromonas caviae ATCC 15468, Aeromonas hydrophila ATCC 35654, Aeromonas veronii biogroup sorbria ATCC 9071, Vibrio parahaemolyticus ATCC 17802, Vibrio vulnificus ATCC 27562, Yersinia enterocolitica ATCC 9610 were given from faculty of Medical Technology, Rangsit University. And also 16 bacteria strains from clinical isolated included Aeromonas caviae, Aeromonas hydrophila, Edwardsiella tarda, Plesiomonas shigelloides, Salmonella arizonae, Shigella boydii, Salmonella choleraesuis, Shigella dysenteriae, Salmonella enteritidis, Shigella flexneri, Salmonella paratyphi, Shigella sonnei, A, Salmonella typhi, Vibrio cholerae, Yersinia enterocolitica, Yersinia pseudotuberculosis

\section{Preparation of bacterial culture}

Individual colonies isolated from $24 \mathrm{~h}$ cultures of tests bacteria were suspended in a sterile $0.85 \% \mathrm{NaCl}$ solution. The suspension was properly inoculated in Trypyic Soy broth. The suspensions were mixed for $15 \mathrm{sec}$ to ensure homogeneity. The turbidity of microbial suspension was diluted to match the turbidity of a $0.5 \mathrm{McF}$ arland standard by spectrophotometry $(\mathrm{OD}=$
$0.08-0.1$ at $625 \mathrm{~nm}$ ) corresponding to $1 \times 10^{8} \mathrm{CFU} / \mathrm{mL}$ and subsequently suspend 1:100 with Trypyic Soy broth to obtain the bacteria containing $1 \times 10^{6} \mathrm{cfu} / \mathrm{mL}$.

\section{Prepare crude water extract from Hibiscus sabdariffa Linn.}

The plant materials were dried under shade and ground into fine powder using an electric blender. For solvent extraction, $5 \mathrm{~g}$ of air dried powder was mixed with $500 \mathrm{ml}$ of sterile water in a conical flask, plugged with cotton and then kept for 24h. After $24 \mathrm{~h}$, it was filtered through Whatman no. 1 filter paper and centrifuged at $5000 \mathrm{~g}$ for $10 \mathrm{~min}$. The filtrates were subject to spray dried until each extract was obtained.

\section{Antibacterial by crude water extraction from Hibiscus sabdariffa Linn.}

The antimicrobial activities of the crude extracts were assayed against bacteria. A test compound was prepared with the known weight of the crude extract, dissolved in distilled water at an initial concentration of $\mathbf{0 . 5 0} \mathrm{g} / \mathrm{ml}$.

The minimum inhibitory concentration (MIC) was determined by using the standard broth micro-dilution method as recommended by the NCCLS and CLSI methodology with a few modifications. The serial two fold dilutions of the crude extracts were made in a concentration which ranged from $200 \mathrm{mg} / \mathrm{ml}$ to $3.125 \mathrm{mg} / \mathrm{ml}$.

Test sample solutions $(50 \mu \mathrm{L})$ and prepared bacterial suspension $(50 \mu \mathrm{L})$ containing $1 \times 10^{6} \mathrm{cfu} / \mathrm{mL}$ were added into each well of the 96-well microplate. Each well of the negative control contained $50 \mu \mathrm{L}$ of microbial suspension and $50 \mu \mathrm{L}$ of Trypyic Soy broth. The microtiter plates were agitated to mix well and then were incubated at $37^{\circ} \mathrm{C}, 16-18 \mathrm{~h}$. All tests were carried out in triplicate. The lowest concentration which showed OD at $620 \mathrm{~nm}$ less than $\mathfrak{R}_{\text {control }}+1.5 \mathrm{SD}$ consider as no growth was taken as the MIC value.

\section{RESULTS AND DISCUSSION}

The antimicrobial activity experiment was conducted using micro-dilution method. The susceptibility testing of crude extract from $H$. sabdariffa showed potent broad spectrum antimicrobial activity which can inhibited six ATCC-registered strains of bacteria, (Table 1). However, the degrees of susceptibility were different depending on pathogen, suggesting that several substances participated in antimicrobial activity.

Among the 6 ATCC-registered strains bacteria used in the present study; the most susceptible microbe were Yersinia enterocolitica ATCC 9610 and Aeromonas veronii biogroup sorbria ATCC 9071 (MIC = $50 \mathrm{mg} / \mathrm{mL}$ ) followed by Vibrio parahaemolyticus ATCC 17802 and Vibrio vulnificus ATCC 27562 (MIC = $100 \mathrm{mg} / \mathrm{mL}$ ). The less susceptible microbe were Aeromonas caviae ATCC 15468 and Aeromonas hydrophila ATCC $35654(\mathrm{MIC}=200 \mathrm{mg} / \mathrm{mL})$. 
Table 1: Minimum inhibitory concentration (MIC) of Hibscus sabdariffa extracts against standard pathogenic bacteria (ATCC strain).

\begin{tabular}{|c|c|c|c|c|c|c|c|}
\hline \multirow{2}{*}{ Organisms tested } & \multicolumn{7}{|c|}{ Concentration of Hibscus sabdariffa extracts (mg/ml) } \\
\hline & 200 & 100 & $\mathbf{5 0}$ & 25 & $\mathbf{1 2 . 5}$ & 6.25 & 3.125 \\
\hline Aeromonas caviae ATCC 15468 & - & - & + & + & + & + & + \\
\hline Aeromonas hydrophila ATCC 35654 & - & - & + & + & + & + & + \\
\hline Vibrio parahaemolyticus ATCC 17802 & - & - & + & + & + & + & + \\
\hline Vibrio vulnificus ATCC 27562 & - & - & + & + & + & + & + \\
\hline Yersinia enterocolitica ATCC 9610 & - & - & - & + & + & + & + \\
\hline Aeromonas veronii biogroup sorbria ATCC 9071 & - & - & - & - & + & + & + \\
\hline
\end{tabular}

Where $(-)=$ growth,$(+)=$ growth.

Table 2: Minimum inhibitory concentration (MIC) of Hibscus sabdariffa extracts against clinical isolated bacteria.

\begin{tabular}{|c|c|c|c|c|c|c|c|}
\hline \multirow{2}{*}{ Organisms tested } & \multicolumn{7}{|c|}{ Concentration of Hibscus sabdariffa extracts (mg/ml) } \\
\hline & 200 & 100 & 50 & 25 & 12.5 & 6.25 & 3.125 \\
\hline A. caviae & - & - & + & + & + & + & + \\
\hline A. hydrophila & - & - & + & + & + & + & + \\
\hline$S$. Enteritidis & - & - & + & + & + & + & + \\
\hline P. shigelloides & - & - & + & + & + & + & + \\
\hline S. Arizonae & - & - & - & + & + & + & + \\
\hline S. Choleraesuis & - & - & - & + & + & + & + \\
\hline S. Paratyphi A & - & - & - & + & + & + & + \\
\hline$S$. Typhi & - & - & - & + & + & + & + \\
\hline S. dysenteriae & - & - & - & + & + & + & + \\
\hline S. boydii & - & - & - & + & + & + & + \\
\hline S. flexneri & - & - & - & + & + & + & + \\
\hline S. sonnei & - & - & - & + & + & + & + \\
\hline V. cholerae & - & - & - & + & + & + & + \\
\hline Y. enterocolitica & - & - & - & + & + & + & + \\
\hline E. $\operatorname{tarda}$ & - & - & - & - & + & + & + \\
\hline Y. pseudotuberculosis & - & - & - & - & + & + & + \\
\hline
\end{tabular}

Where $(-)=$ growth, $(+)=$ growth.

In addition, the degrees of inhibition among clinical isolated bacteria were shown in Table 2. The most susceptible microbe were E. tarda and Y. pseudotuberculosis $(\mathrm{MIC}=50$ $\mathrm{mg} / \mathrm{mL}$ ) followed by $P$. shigelloides, S. Arizonae, S. Choleraesuis, S. paratyphi A, S. typhi, S. dysenteriae, S. boydii, S. flexneri, S. sonnei, $V$. cholerae, $Y$. enterocolitica and A. caviae showed similar MIC as $50 \mathrm{mg} / \mathrm{mL}$. The less susceptible microbe were $A$. hydrophila and $S$. enteritidis (MIC $=100 \mathrm{mg} / \mathrm{mL}$ ).

Interestingly, crude extract from $H$. sabdariffa can inhibit ATCC-registered strains bacteria by MIC range from 50-200 $\mathrm{mg} / \mathrm{mL}$. However it can inhibit clinical isolated bacteria by MIC range from $25-200 \mathrm{mg} / \mathrm{mL}$. In addition, crude extract also exhibited its antibacterial activities on enteric pathogens giving the lowest MICs of $25 \mathrm{mg} / \mathrm{ml}$ on Edwardsiella tarda and Yersinia pseudotuberculosis. Taken together, crude extract from $H$. sabdariffa showed activity against all strain of tested bacteria used in this study. This finding was correlated with previous work reported that methanol extract from $H$. sabdariffa can inhibit $E$. coli $\mathrm{O} 157: \mathrm{H} 7$ isolated from food, veterinary, and clinical samples (Fullerton et al., 2011). Other study was reveal that aqueousmethanolic extract of $H$. sabdariffa exhibited antibacterial activities (MIC $0.30 \pm 0.2-1.30 \pm 0.2 \mathrm{mg} / \mathrm{ml}$ ) against $S$. aureus, $B$. stearothermophilus, M. luteus, Serratia marcescens, Clostridium sporogenes, E. coli, K. pneumoniae, B. cereus, P. fluorescence (Olaleye et al., 2007).

According to biological activities of $H$. sabdariffa, the antimicrobial activity may be the result of phenolic compounds, including flavonoids. Flavonoids are hydroxylated phenolic substances but occur as a C6-C3 unit linked to an aromatic ring. These compounds have the ability to form a combined complex with bacterial cell walls. Also, with the number of hydroxyl groups present on the phenolic ring. There is increased hydroxylation, and with increased hydroxylation there will be increased antimicrobial activity (Cowan, 1999). Flavonoids are known to be synthesized by plants in response to microbial infection, it should not be surprising that they have been found in vitro to be effective antimicrobial substances against a wide array of microorganisms (Fullerton et al., 2011).

In the treatment of infectious diseases, the use of plants is common in traditional medicine. The study showed that the aqueous crude extracts had wide ranges of activity on the selected pathogenic strains. The results indicate that this extracts may contain active components that produced antimicrobial against the selected enteric pathogenic strains. The medicinal plants' value lies in chemical substances that produce a definite physiological action on the pathogens. The biologically active compounds present in plants have the potential for development as medicinal agents.

There is a need for the development of new antimicrobial drugs from medicinal plants to treat infectious diseases; these may be less toxic to humans and have novel mechanisms of action. The plants which showed the highest antibacterial activity can be further subjected to isolation of the therapeutic antimicrobial compounds and evaluated pharmacologically. The study confirmed that $H$. sabdariffa showed maximum inhibitory activity can be used for the treatment of infectious diseases. In the current 
study, this finding suggests that crude extracts from $H$. sabdariffa showed a wide spectrum of antimicrobial activity. It is clear that H. sabdariffa has antibacterial activities against enteric pathogens. Antibacterial resistance especially among Gram negative bacteria is an important issue that has created a number of problems in treatment of infectious diseases and necessitates the search for alternative drug or natural antibacterial. This aspect of antimicrobial activity will be further investigated to enhance production of secondary metabolites of interest. Therefore, any information and research on $H$. sabdariffa plant is of value.

\section{CONCLUSIONS}

Our study confirmed that $H$. sabdariffa was effective at all entero pathogenic bacteria both ATCC-registered strains and clinical sources. This shows that plant extracts possess antimicrobial activity and hold great promise as antimicrobial agents against foodborne pathogens. In addition, micro-dilution method provided quantitative data that reliably predicted the effectiveness of antimicrobial activity of the extracts. Plant extracts may be used as possible sources to obtain new and effective herbal medicines to treat foodborne infections, as they may be an excellent alternative to combat the further spread of multidrug-resistant microorganisms. It is important, however, to determine toxicity of the active constituents, their side effects, and pharmacokinetic properties. Future studies need to address these compounds from various type extractor and also determine their effectiveness on other microbial such as parasite and fungi. Therefore, the use of natural antimicrobials from $H$. sabdariffa and their application are major goals of current research to accomplish environment-friendly technological development.

\section{ACKNOWLEDGMENT}

Financial support and sponsorship: Financial support from faculty of medical technology, Rangsit University is gratefully acknowledged.

Conflict of Interests: There are no conflicts of interest.

\section{REFERENCES}

Abdalla EM. Plants: An alternative source for antimicrobials. J App Pharm Sci, 2011; 1:16-20.

Akindahunsi AA, Olaleye MT:Toxicological investigation of aqueous methanolic extract of Hibscus sabdariffa L. J Ethnopharmacol 2003;89:161-164.

Chen CC, Hsu JD, Wang SF, Chrang HC, Yang MY, Kao ES, Ho YO, Wang CJ Hibscus sabdariffa extract inhibit the development of atherosclerosis in cholesterol-fed rabbits. J Agric Food Chem, 2003; 51: 5472-5477.
Cowan MM Plant products as antimicrobial agents. Clin Microbiol Rev 1999;12:564-582.

Dalziel JM. 1973. The useful plants of west tropical Africa. London: The Crown Agents.

Duke J. A. Ecosystematic data on economic plants, Quart. J. Crude Drug Res, 2011; 17:91-110

Fullerton MSC, Verghese M, Walker LT, Shackelford LA, Cebert E, Boateng J, Ogutu S, Khatiwada J, Guyton M, Jones J, Chawan $\mathrm{CB}$ Determination of antioxidant contents in red sorrel and its anticarcinogenic potential in azoxymethane-induced colonic aberrant crypt foci. J Res Phytochem, 2008; 2: 69-76.

Fullerton MSC, Khatiwada J, Johnson JU. Determination of antimicrobial activity of Sorrel (Hibiscus sabdariffa) on Esherichia coli O157:H7 isolated from food, veterinary and clinical samples J Med Food, 2011; 14: 950-956.

Jonadet M, Bastide J, Bastide P, Boyer B, Carnat AP, Lamaison $\mathrm{JL}$ In vitro enzyme inhibitory and in vivo cardio-protective activities of Hibiscus sabdariffa L. J Pharmacol Belgium, 1990; 45: 120-124.

Liu C, Wang J, Chu C, Cheng M. Tseng T In vivo protective effect of protocatechuic acid on tert-butyl hydroperoxide-induced rat hepatotoxicity. Food Chem Toxicol, 2002; 40: 635-641.

Mahadevan N., Shivalic Kamboj P. Hibiscus sabdariffa Linn An overview. Natural Product Radiance, 2009; 8: 77-83.

Morton J.F. Roselle. 1998. In: Fruits of warm climate. Dowling, C.F.(Ed.) Media Inc. Greensboro, NCP. pp: 281-286.

Odigie IP, Ettarh RR, Adigun SA Chronic administration of aqueous extract of Hibscus sabdariffa attenuates hypertension and reverses cardiac hyperytrophy in $2 \mathrm{~K}-1 \mathrm{C}$ hypertensive rats. J Ethnopharmacol, 2003; 86: 181-185.

Olaleye MT. Cytotoxicity and antibacterial activity of methanolic extract of Hibiscus sabdariffa J Med Plants Res, 2007; 1:009013.

Prerry LM. 1980. Medicinal plants of east and southeast Asia. Cambridge: MIT Press, Cambridge 1980.

Rao PU. Nutrient composition and biological evaluation Mesta (Hibiscus sabdariffa) seeds.Plant Foods Hum Nutr, 1996; 49:27-34.

Thapar N, Sanderson IR. Diarrhoea in children: an interface between developing and developed countries. Lancet 2004; 363: 641-653.

Wang CJ, Wang JM, Lin WL, Chu CY, Chou FP, Tseng TH Protective effect of Hibiscus anthocyanins against tert-butyl hydroperoxide-induced hepatic toxicity in rats. Food Chem Toxicol, 2000; 38: $411-416$.

World Health Organization. 2009. Why children are still dying and what can be done. WHO Bulletin [ONLINE] Available: http://www.who.int/child_adolescent_health/documents/9789241598415/e n/index.html. [Accessed 20 March, 2012]

\section{How to cite this article:}

Jantrapanukorn B, Pongpraritt S, Powthong P, Pheungphu T. The study of antibacterial activity in enteric pathogens of Roselle (Hibiscus sabdariffa Linn.) by broth micro-dilution method. J App Pharm Sci, 2017; 7 (05): 119-122. 